\title{
Communication
}

[Comunicação]

\section{Identification of Candida species isolated from cows suffering mastitis in four Brazilian states}

\author{
[Identificação de espécies de Candida isoladas de vacas com mastite \\ em quatro estados Brasileiros] \\ L.C.A. Sartori ${ }^{1}$, R.C. Santos ${ }^{1}$, J.M. Marin ${ }^{2 *}$ \\ ${ }^{1}$ Faculdade de Ciências Agrárias e Veterinárias de Jaboticabal - UNESP - Jaboticabal, SP \\ ${ }^{2}$ FORP-USP - Campus Ribeirão Preto - SP
}

\begin{abstract}
Mammary gland inflammation (mastitis) continues to be the most frequent and expensive disease of dairy cows (Zaragoza et al., 2011). It negatively influences the economic effectiveness of farms and the hygienic quality of milk (Bradley, 2002). More than 135 different microorganisms have been found as etiological agents of mastitis (Watts, 1988; Bradley, 2002). In addition to bacterial agents, several other groups of microorganisms such as yeasts, molds and algae can cause an inflammatory process and alteration in the udder (Krukowski et al., 2006; Spanamberg et al., 2009). Although the incidence of mastitis due to fungi is usually low in dairy herds, sometimes they have been associated with clinical mastitis in dairy cattle (Spanamberg et al., 2009).
\end{abstract}

Fungi are found in the soil and may colonize udder skin in small numbers. They are considered to be opportunists (Bradley, 2002) and produce disease when natural defense mechanisms are lowered. Candida species are the most frequent organisms among the mycotic mastitis agents isolated from infected glands and are commonly related with post-treatment with antimicrobial agents (Spanamberg et al., 2009; Zaragoza et al., 2011). There are reports in the literature about the occurrence of yeasts in milk and cheese from bovine (Spanamberg et al., 2009). The presence of microorganisms in milk, many of which are responsible for zoonoses, represents a factor that compromises its quality and safety. The aim of the present study was to

Recebido em 14 de abril de 2014

Aceito em 10 de setembro de 2014

*Autor para correspondência (corresponding author)

E-mail: jmmarin@forp.usp.br isolate and identify Candida species from mammary glands of cows with clinical and subclinical mastitis.

The study was carried out with cows from dairy farms, raised under the intensive system of husbandry, distributed in four Brazilian States, São Paulo (six farms), Paraná (14 farms), Santa Catarina (seven farms) e Rio Grande do Sul (14 farms). The herds were constituted by animals with different breeds, ages and at different lactation phases. The clinical mastitis was characterized by clinical signs and/or abnormal milk secretion detected by the strip cup test. Subclinical mastitis was identified by the conventional CMT (California Mastitis Test). For this study, milk samples were included when the reaction to CMT was at least grade1, corresponding with an appearance of viscous milk that does not adhere to the bottom of the CMT plate, and correlates to 400,000-1,500,000 somatic cells $/ \mathrm{mL}$. Four-hundred-twenty-eight milk samples from quarters with clinical or subclinical mastitis were collected from February to December 2009. Milk samples $(10 \mathrm{ml})$ were always aseptically collected in sterile glass bottles after disinfection of the teats with alcohol $70 \%$ and kept at a temperature of $4^{\circ} \mathrm{C}$ until processing at the laboratory. Aliquots of $0.1 \mathrm{~mL}$ of milk were spread on Sabouraud dextrose agar (SDA, Oxoid CM0041) supplemented with chloramphenicol $(400 \mathrm{mg} / \mathrm{L})$. The plates were incubated at $37^{\circ} \mathrm{C}$ for $72 \mathrm{~h}$. The yeasts were phenotypically characterized by standard tests (Barnett et al., 1990). Among the fungi isolates 
only Candida genus was used in this study. After identification, one isolate from each plate was maintained in Sabouraud dextrose agar slants and kept at room temperature.

Among the milk samples, fifty-five of them were positive for Candida (12.8\%). The species of Candida isolated from cows with mastitis are presented in Table 1.

Table 1 Candida species identified from cases of bovine mastitis in 41 dairy herds in four Brazilian states in 2009

\begin{tabular}{lcc}
\hline Species & Number & Percentage \\
\hline C. krusei & 19 & 34.6 \\
C. parapsilosis & 14 & 25.4 \\
C. tropicalis & 10 & 18.2 \\
C. albicans & 7 & 12.8 \\
C. glabrata & 2 & 3.6 \\
C. spp. & 2 & 3.6 \\
C. rugosa & 1 & 1.8 \\
Total & 55 & 100 \\
\hline
\end{tabular}

Candida is commonly viewed as an opportunistic yeast pathogen. In the normal host, the yeast has evolved to become a successful commensal. It expresses variant traits critical for existence on mucosal surfaces. In abnormal circumstances, the same traits become virulence characteristics what increase the invasive abilities of the yeast (Bradley, 2002; Edelman et al., 2005). An important increase in the number of udder infections caused by Candida species and other yeasts was reported in various countries in recent years (Lagneau et al., 1996; Santos and Marin, 2005; Krukowski et al., 2006; Seker, 2010; Zaragoza et al., 2011). In the present study, the percentage of Candida isolation was $12.8 \%$. This rate is almost equal the rate reported recently by Seker (2010) in Turkey $12.7 \%$ and near the rate reported by Santos and Marin (2005) in Brazil, 17.3\%. Although the distribution of Candida species shows diversity in several surveys, $C$. krusei, C. parapsilosis, $C$, tropicalis, C. albicans, C. glabrata, $C$. famata and $C$. rugosa have been demonstrated as the most common species isolated from mycotic mastitis (Santos and Marin 2005; Krukowski et al 2006; Seker 2010; Zaragoza et al., 2011), most of them also isolated in the present study. C. krusei accounted for more than one third of the strains isolated (Table 1) in agreement with a previous description of Santos and Marin (2005) and also with a recent report of Seker (2010). Certainly exists differences involving places, time and type of mastitis. Santos and Marin (2005) found a great number of C. rugosa and C. guilliermondii and a small number of $C$. tropicalis and $C$. parapsilosis strains in dairy herds in São Paulo and Minas Gerais states, showing mainly subclinical mastitis. In the present study, the isolates mainly came from Paraná and Rio Grande do Sul states and from cows with clinical mastitis and in that case a great number of $C$. parapsilosis and C. tropicalis were isolated.

Lagneau et al. (1996) mentioned that an important pathogenic characteristic of mastitic yeast isolates is their ability to grow at temperatures above $40{ }^{\circ} \mathrm{C}$. Among the Candida species isolated in this study at least C. krusei and $C$. albicans showed this ability. The hemolysin production has also been considered as a virulence factoring the Candida pathogenesis. Seker (2010) reported C. krusei, $C$. kefir, C. albicans, C. tropicalis, C. zeylanoides and $C$. glabrata showing in vitro hemolytic activity what is consistent with the hemolytic activities of different Candida isolates obtained from humans (Nedret Koç et al., 2002).

Although $C$. albicans remains the most frequent cause of fungemia, a number of reports have documented infections caused by $C$. tropicalis, C. glabrata, C. parapsilosis, C. krusei and $C$. lusitaniae (Rodrigues et al., 2010). Considering that animals could be vectors of transmission or reservoirs of strains causing human disease and may present a risk for immunocompromised patients (Edelman et al., 2005), a special attention must be given to dairy products. Nedret Koç et al (2002) reported 12 cases of C. glabrata fungemia occurred in hospitalized children in a Turkey hospital due to milk contamination. Therefore, it should be concluded that fungal mastitis will become an increasing problem due to the increase participation of this microorganism in mastitis and also due to their potential risk for public health by milk contamination.

Keywords: cow, bovine mastitis, milk, yeast, Candida 


\section{RESUMO}

A mastite representa um dos problemas mais sérios que afetam as fazendas de gado leiteiro. As mastites clínica e subclínica em bovinos, devido a leveduras, são causadas principalmente por espécies do gênero Candida. $O$ objetivo deste trabalho foi identificar quais espécies dessa levedura estavam presentes em amostras de leite obtidas da glândula mamária de vacas apresentando mastite. Um total de 428 amostras de leite foi coletado nos estados de São Paulo, Paraná, Santa Catarina e Rio Grande do Sul. A identificação foi realizada por meio de critérios fenotípicos e fisiológicos. Foi possível isolar seis espécies de Candida em 55 (12,8\%) das amostras. As espécies mais frequentes foram C. krusei (34,6\%), C. parapsilosis $(25,4 \%)$, C. tropicalis $(18,2 \%)$ e C. albicans $(12,8 \%)$. Esses resultados sugerem que outras espécies de Candida, além da $\mathrm{C}$. albicans, possuem um papel importante em mastites micóticas em vacas.

Palavras- chave: vaca, mastite bovina, leite, levedura, Candida

\section{REFERENCES}

BARNETT, J.A.; PAYNE, R.W.; YARROW, D. Yeast Characteristics and Identification. 2.ed. Cambridge: Cambridge University Press, 1990, 1012p.

BRADLEY, A.J. Bovine mastitis: an evolving disease. Vet. J., v.164, p.116-128, 2002.

EDELMAN, A.; KRUGER, M.; SCHIMIDT, J. Genetic relationship between human and animal isolates of Candida albicans. J. Clin. Microbiol., v.43, p.6164-6166, 2005.

KRUKOWSKI, H.; LISOWSKI, A.; RÓZANSKI, P.; SKÓRKA, A. Yeast and algae isolated from cows with mastitis in the South-eastern part of Poland. Polish J. Vet. Sci., v.9, p.181-184, 2006.

LAGNEAU, P.E.; LEBTAHI, K.; SWINNE, D. Isolation of yeast from bovine milk in Belgium. Mycopathologia, v.135, p.99-102, 1996.

NEDRET KOÇ, A.; KOCAGOZ, S.; ERDEM, F.; GUNDUZ, Z. Outbreak of nosocomial fungemia caused by Candida glabrata. Mycosis, v. 45, p.470-475, 2002.
RODRIGUES, D.; ALMIRANTE, B.; CUENCAESTRELA, M. et al. Predictors of candidemia caused by non-albicans Candida species: results of a population-based surveillance in Barcelona, Spain. Clin. Microbiol. Infect., v.16, p.16761682, 2010.

SANTOS, R.C.; MARIN, J.M. Isolation of Candida spp. from mastitic bovine milk in Brazil. Mycopathologia, v.159, p.251-253, 2005.

SEKER, E. Identification of Candida species isolated from bovine mastitic milk and their in vitro hemolytic activity in Western Turkey. Mycopathologia, v.169, p.303-308, 2010.

SPANAMBERG, A.; SANCHES, E.M.C; SANTURIO, J.M; FERREIRO, L. Mastite micótica em ruminantes causada por leveduras. Cienc. Rural, v.39, p.282-290, 2009.

WATTS, J.L. Etiological agents of bovine mastitis. Vet. Microbiology, v.16, p.41-66, 1988.

ZARAGOZA, C.S.; OLIVARES, R.A.C.; WATTY, A.E.D. et al. Yeast isolation from bovine mammary glands under different mastitis status in the Mexican High Plateu. Rev. Iberoamericana de Micol., v.28, p.79-82, 2011. 